\title{
The Bonds of Freedom: Heidegger and Hochschild on Affective Life and Affective Labour KAREN ROBERTSON
}

None of us are born with pre-formed attachments to specific others, to specific places, or to specific activities. Indeed, the activities and relationships that comprise a life can be properly taken up only when we are attuned to them as the meaningful sites of our self-realization. Thus, while our affective attachments are shaped by contingencies of our homes, cultures, historical moments, and so on, they are also characterized by an inherent indeterminacy. This paper draws on Martin Heidegger's work in Being and Time to consider the relationship between the open indeterminacy of affective life and its inevitable specificity, proposing that this relationship is central to our capacity to realize ourselves meaningfully as free beings. Further, connecting sociologist Arlie Hochschild's study of affective labour to Heidegger's work, this paper aims to demonstrate that affective labour - emotional work done in a commercial setting - risks substantially undermining our capacity for free self-realization. Finally, aligning Heidegger's insights with those of Hochschild, we conclude that the freedom that defines us is both socially constituted and our responsibility; together, we are responsible for realizing the possibilities upon which we all depend.

To begin, an overview of Heidegger's account of human existence will frame our analysis of affective life and enable us to understand affective life as: ${ }^{1}$ (a) an accomplished attachment to the specificities of our world, (b) grounded on socially constituted significance, and (c) an aspect of our existence for which we are responsible. We will also identify vulnerabilities associated with each of these aspects of affective life. The account of these vulnerabilities will ground a critique of affective labour practices in postindustrial modernity. Accordingly, the second and third sections of this paper will draw on Hochschild's 1983 The Managed Heart: The Commercialization of Human Feeling to illustrate how affective labour challenges significantly our ability to live responsibly and well with one

\footnotetext{
${ }^{1}$ Heidegger explains clearly that the phenomenon he investigates under the appellation "state-of-mind" is ordinarily called "affects" or "feelings" (see BT 177-178/138-139). I will indicate references to Being and Time with " BT," followed by English then German pagination.
} 
another. $^{2}$ There, we begin by summarizing Hochschild's account of emotional life and her study of the affective labour of airline stewards and stewardesses. Drawing on these accounts, we come to see that communication plays a central role in the way that affective labour undermines the social basis of affective life, and, in so doing, threatens our ability to live out of the affective experiences specific to our world and exacerbates our tendency to disavow our responsibility for individual and collective possibilities of affective life. Next, we return to Heidegger's work to demonstrate its compatibility with Hochschild's; in both cases, affective labour limits our freedom by preventing us from realizing our freedom properly as a meaningful attachment to the specificities of our world. We conclude by clarifying how affective labour exacerbates the vulnerabilities of affective life and by recognizing that we must take responsibility for this situation inasmuch as the demand for affective labour signals the depletion of shared ways of living meaningfully out of the specificities of our lives, relationships, and personal or professional projects. In this recognition of responsibility, the social character of freedom is disclosed.

By orienting Heidegger's work towards concrete "ontic" problems in the domain of human life, I am departing from the standard interpretation which views the authenticity of Dasein to be accomplished through individuation rather than through a meaningful involvement in the world. ${ }^{3}$ Such readings, as I hope to demonstrate, overlook the substantial resources Heidegger's work afford for analysing and understanding features of our shared, worldly reality - features more prominent in Heidegger's work subsequent to Being and Time, such as the essays "Building, Dwelling, Thinking" or "The Origin of the Work of Art." " Other scholars who orient Heidegger's work to analyses in the social sciences and beyond include Stuart Elden, Daniel Ratcliffe, and Richard Polt whose works highlight the worldly character of Dasein. ${ }^{5}$ By arguing for a basic compatibility between

${ }^{2}$ Even if the labour practices under investigation here are associated with late modernity, while we are, arguably, now in a different and changing global economic and political reality, this analysis remains relevant insofar as it focuses on labour practices that remain in place today. For an account of the prevalence of affective labour that is more contemporary than Hochschild's, see Steinberg and Figart.

${ }^{3}$ For example, William Richardson offers an account of mood without any reference to others (64-66).

${ }^{4}$ In The Genesis of Heidegger's Being and Time, Kisiel connects Heidegger's analysis in Being and Time to Heidegger's 1919 lecture courses by demonstrating the connection between Being and Time and the issue of a worldview (44-47).

${ }^{5}$ See for example, Stuart Elden: "Contributions to Geography? The Spaces of Heidegger's Beiträge," Environment and Planning D: Society and Space 23 (2005): 811-827; “Taking the Measure of the Beiträge: Heidegger, National Socialism and the Calculation of the Political," European Journal of Political Theory 2.1 (2003): 35-56; "Rethinking the Polis: Implications of Heidegger's Questioning the Political," Political Geography 19.4 (2000): 407-422. Richard Polt considers Heidegger's potential understanding of liberalism in 
Heidegger's approach to social significance, on the one hand, and Hochschild's critique of affective labour, on the other hand, I hope to contribute to this general trend in Heidegger scholarship.

\section{Freedom and Specificity: Heidegger on Affective Life}

Rather than concern itself with Heidegger's ontological inquiry as a whole, this paper addresses a theme found intermittently throughout Heidegger's corpus, not only in his 1927 Being and Time, but also, for example, in his 1936 Contributions to Philosophy: From Enowning, his comments on the affective experience of poets in his work on language in the 1950's, and his late Zollikon Seminars. ${ }^{6}$ In Being and Time, Heidegger's account of affective life falls within his analysis of the basic constitution of human existence-Dasein. ${ }^{7}$ A brief summary of Heidegger's account of Dasein will be helpful for framing a more focussed discussion of state-of-mind [Befindlichkeit], the constitutive feature of Dasein's existence that presents itself ontically as mood, feeling, or affect. ${ }^{8}$ After this summary, we will turn to a more detailed account of state-of-mind, and, finally, to the three aspects of affective life identified above (its accomplished character, its social character, and our responsibility for it) as our way of realizing our basic existential attachment to the world and, therefore, as ways that this basic attachment can be threatened.

"Metaphysical Liberalism in Heidegger's Beiträge Zur Philosophie," Political Theory 25.5 (October 1997): 655-679. Daniel Ratcliffe links Heidegger's work to neuropsychology. Meanwhile, Frank Schalow, Charles Guignon, Hubert Dreyfus and Charles Scott all clarify the implications of Heidegger's analysis for our individual experience. As Charles Scott writes, contrasting Dasein's everyday self to the self-understanding that arises with an understanding of our Being, "Heidegger uses self to refer to 'who' dasein is. The term is meant to suggest not universality but the relative activity of a socialized, acculturated individual making its way in life" (105).

${ }^{6}$ For Heidegger's remarks on affective life in Contributions, see 15-17/19-21, 162/228230. For his remarks on the affective experience of poets, see, for example, On the Way to Language 64-65. Heidegger's 1929 lecture "What is Metaphysics?" also includes an important discussion of mood; according to de Beistegui, Heidegger's 1928 treatment of mood in The Fundamental Concepts of Metaphysics is essential to overcoming metaphysics (de Beistegui 62).

${ }^{7}$ See BT §29, §30, §68. For a summary of Heidegger's early accounts of mood and emotions, see Ratcliffe.

${ }^{8}$ There is considerable debate in Heidegger scholarship relating to the translation of "Befindlickheit." I retain Macquarrie and Robinson's translation, using "state-of-mind" for "Befindlichkeit" and "mood" for "Stimmung," the latter of which is sometimes translated as "attunement" (see Heidegger, Fundamental Concepts of Metaphysics). For accounts of ways that "Befindlichkeit" has been translated, as well as the limitations of each translation, see Freeman; Flatley chapter 1, ftn. 34; Elpidorou. 
With his account of Dasein - the "there-being" of the human being-Heidegger challenges the modern philosophical understanding of the human being as a discrete and fundamentally rational being. He proposes, instead, that human existence be understood as a meaningful involvement that takes the form of primordially related existential structures that enable self-experience, what Heidegger calls "Being-in-the-world." As Being-in-the-world, Dasein makes manifest the everyday world populated by others and rendered meaningful through human art, practices, traditions, institutions, and so on; simultaneously, Dasein realizes itself through its irreducible attachment to these and to the specificities they contextualize. Such attachments, moreover, are realized as and within affective life, and Dasein's self-experience is constituted largely, therefore, by its affective bonds with the world.

It is Dasein's worldly way of experiencing itself, rather than a foundational ego, that constitutes the self of Dasein. Heidegger intends the foundational character of self-experience when he explains that "The "essence' ["Wesen"] of this entity lies in its 'to be' [Zu-sein]" and that, "Because Dasein has in each case mineness [Jemeinigkeit], one must always use a personal pronoun when one addresses it: 'I am', 'you are'" (BT 6768/42). Foundational self-experiences are experiences of possibilities of our existence, possibilities that are manifest to us in terms of the world to which we are attached. Accordingly, indeterminacy is central to our existence: inasmuch as our existence is defined by self-experience that occurs in terms of possibilities, we are essentially undetermined and always in the process of becoming ourselves. We are free. Meanwhile, only because freedom and indeterminacy are central to self-experience can we be involved in the world in the first place. Accordingly, our worldly involvement realizes our freedom, and our freedom is, in that sense, affectively constituted as our attachment to the specificities of the world in which we are involved. ${ }^{9}$ Before acquiring a more robust sense of affective life as a site in which we realize our freedom, let us consider the existential structures that constitute our existence.

\footnotetext{
${ }^{9}$ In Being and Time, Heidegger does not use the term "free" to discuss the Being disclosed in anxiety, although he does emphasize the indeterminacy of our Being (BT 231/188) as well as the necessity that this Being be in the world (BT 235/190). In his slightly later "What is Metaphysics?", however, Heidegger explains that in anxiety Dasein is held out into "the nothing" and there experiences its uncanniness and freedom: "Without the original manifestation of the nothing, no selfhood and no freedom" (Pathmarks 91). Similarly, de Beistegui remarks on the uncanniness that pervades Dasein's worldly existence; "the thematic of the Unheimlichkeit runs through the whole of Heidegger's thought and constitutes the ground whence Heidegger thinks the phenomena of Being-inthe-world, dwelling, having a home, and, on this basis, the ideas of homeland, nation, community" (de Beistegui 65). Furthermore, as de Beistegui also explains, in The Fundamental Concepts of Metaphysics, Heidegger describes how Dasein encounters its freedom through its existential boredom (de Beistegui 73-74).
} 
According to Heidegger, our existence has three basic dimensions: understanding [Verstehen], state-of-mind or attunement [Befindlichkeit], and discourse [Rede]. ${ }^{10}$ While united in principle, each existential structure plays a unique role in realizing Dasein's otherwise unitary existence and in determining the possibilities of a particular Dasein. ${ }^{11}$ First, understanding is Dasein's capacity to exist as potential - as futural and inclined towards self-realization. It ensures the worldliness of Dasein's experience through a basic and immediate grasp of the contexts in which Dasein finds itself. ${ }^{12}$ Second, while more will be said of state-of-mind shortly, we can recognize its cooperative involvement with the other existential structures by understanding it as the phenomenon through which Dasein's world is compelling to it. Third, discourse articulates, and thereby makes specific and public, the world disclosed by understanding and rendered important to Dasein by state-of-mind. Notably, it is through discourse, which always expresses state-of-mind, that Dasein shares a particular world with others. To summarise the basic existential structure of Dasein, understanding gives rise to an experience of the world in terms of which Dasein's existence is at stake; state-of-mind renders significant to Dasein the specific aspects of the world that colour its sense of itself and its world; discourse houses worldly significance.

If affective life is what makes the world compelling, then it enables us to experience explicitly our worldly involvement as an articulation of freedom. Affective life, then, does not simply disclose how we are feeling. Existentially speaking, there is no discrete "I" who is involved in various contexts - as citizen, customer, service-recipient, employer, and so onand who feels one way or another about such involvements. Rather, one's factical, objective involvements are grounded on how one is attuned to the world in general (state-of-mind) and on the various ways the world is disclosed (mood). Attunement, in these two senses, is a foundational mode of involvement realized as one's way of experiencing oneself in terms of what one finds compelling. Thus, affective life is a foundational experience

\footnotetext{
${ }^{10}$ Heidegger adds that our constitutive failure to recognize the character of our existence constitutes an originary tendency that he refers to as "fallenness" [Verfallenheit]. "Fallenness" is understood as an irreducible feature of our existence even if it is not (always) marked as constitutive of our foundational openness to a world. For his account of this phenomenon, see BT 220/176.

${ }^{11}$ Heidegger refers to these as the "unitary primordial structure of Dasein's Being" (BT 169/130).

12 According to Heidegger, a basic understanding of Being is also always disclosed in the projection of the understanding. This is why Dasein must be understood existentially and why the understanding of Being is a hermeneutical project-why it involves discovering, in our very ways of thinking and experiencing, the always partial understanding of Being that shapes our experience (see BT 187-188/147-148).
} 
of our very way of existing and discloses us to ourselves as such a mode of existence: "the mood brings Dasein before the 'that-it-is' of its 'there'" (BT 175/136). One finds oneself always to be in one mood or another (BT 174/134), and, as disclosed to oneself thereby, never able to escape oneself.

Our inevitable self-experience is also (nearly) always an experience of worldly circumstances and can therefore conceal the isolating individuality of all self-experience. States-of-mind, Heidegger explains, "disclose Dasein in its thrownness, and-proximally and for the most partin the manner of an evasive turning away" (BT 175/136, emphasis in original). Being thrown into a specific world involves turning, simultaneously, away from how our existence is foundational for the world's significance and facticity. ${ }^{13}$ Yet, as beings who enact the significance out of which we live, we are nevertheless unfamiliar with ourselves as meaning-enacting agents. When the foundational "rendering meaningful" that is our existence is grasped in and of itself, "it stares it in the face with the inexorability of an enigma" (BT 175/136). The enigma of our existence remains forever latent in state-of-mind while, for the most part, affective life enables us to experience our world as a matter of fact. Affective life is, accordingly, two-fold: it orients us meaningfully towards the world, on the one hand, and it bears and discloses our concrete existence, on the other hand. The worldly attunements that constitute our concrete existence are responses to the otherwise indefinite and enigmatic possibility of existing that constitutes our freedom.

The compelling character of our freedom is experienced affectively in two basic ways: (a) in terms of the way that specific contexts and possibilities to stand out against a background of all the possible projects and relationships we do not take up, and (b) with respect to the basic terms of significance that constitute our experience. Heidegger attributes the compelling character of the possibilities we chose to pursue to their embeddedness in a larger whole from which they stand out: "The mood has already disclosed, in every case, Being-in-the world as a whole, and makes it possible first of all to direct oneself towards something" (BT 176/137). By situating us in a context that exceeds us, affective life imbues our specific projects with the significance of being chosen among other possibilities. Meanwhile, the context that makes possible our choices is not disclosed to us as a totality of entities, facts, and possible lifestyles; rather, it contextualises by disclosing the standards in terms of which our lives can be meaningful. What is most fundamentally disclosed to us, then, are the basic measures that characterize a world: "Existentially, a state-of-mind implies a disclosive submission to the world, out of which we can encounter something that matters to us" (BT 177/137, emphasis in original).

\footnotetext{
${ }^{13}$ In Haugeland's account, Befindlichkeit refers to Dasein's finding itself in the midst of its
} "throwness," the particular situation to which it must attend practically (36-37). 
Disclosive submission consists, for example, in whether possibilities are experienced as those of an individual or of a member of a community, or whether greatness is understood in terms of public self-enactment or in terms of the potential to purify one's soul. ${ }^{14}$ Our attachment to a world is accomplished through our submission to and appropriation of the general terms and possibilities required for a more definite experience of significance. ${ }^{15}$ We live meaningfully by understanding our specific possibilities as ways of realizing basic significances disclosed to us through affective life, and it is as such meaningful choices that we experience our freedom compellingly.

The relationship between the existential character of affective life and our experience of freedom has some consequences for our concrete everyday experience of affective life. ${ }^{16}$ Let us consider how, in its everyday sense, affective life is (a) accomplished, (b) public and socially constituted, and (c) our responsibility. In so doing, we will come to see that each of these three aspects of affective life is associated with specific risks and vulnerabilities.

By the "accomplished" character of affective life, I mean that our basic capacity to feel a certain way must have been shaped and educated so as to correspond to the way circumstances actually may affect us. ${ }^{17}$

${ }^{14}$ Dreyfus distinguishes between similar possibilities in "Heidegger's Ontology of Art." More concretely, Guignon notes, "In our world, we can be consumers and producers, but not vassals and seigneurs" ("Moods in Heidegger's Being and Time" 183).

${ }^{15}$ It is at this level that a distinction could be made between moods, which disclose Dasein to itself, and what might be called "feelings" or "emotions" which are arguably oriented towards Dasein's intentional ability to negotiate its world. On this distinction, see Crowell 9-10.

${ }^{16}$ With its orientation towards the sociological, and therefore ontic, dimension of human existence, this paper brings Heidegger's work to bear on an issue that falls outside of the scope of the ontological work of Being and Time. For this reason, I have made sure to connect what I take to be the concrete features of Heidegger's account of affective life to his analysis of Dasein's ontological constitution. It is also worth noting that the limitation of freedom I am focussing on resonates with Heidegger's critique of the fundamental mood of boredom characteristic of the modern world (see Fundamental Concepts of Metaphysics; de Beistegui 68-80). His claims, in "The Origin of the Work of Art," on the impossibility of art in the modern world and on the art "industry" also resonate with my analysis (see Off the Beaten Track). For further ways of connecting Heidegger's work to the contemporary world, consider accounts of the relationship between Heidegger's thinking and capitalism, see Ziarek; Malabou. There is also the idea that Being and Time is related to Heidegger's experience of capitalism (see Coletti 172-173). In Confrontation with Modernity, Zimmerman considers the relationship between commercialism and the conservative Volkish movement in Germany (10).

${ }^{17}$ Elpidorou expresses this point nicely: "Hence, in order to experience something as threatening or hostile, as lovely or enjoyable, or even as indifferent, we must already be in a mood" (569). Elpidorou also emphasises the affective, rather than cognitive, character of what moods disclose. 
Heidegger endorses such a view when he explains that our capacity to be affected [Betroffenwerdens] depends on that with which we involve ourselves (BT 176/137). ${ }^{18}$ For example, a teacher may respond to changes in policies dictating the number of students per class with anger or apprehension. Yet, only through the appropriate attunement will she experience potential policy changes in terms of the basic possibility to which she committed. Her feelings are meaningful insofar as they reflect her commitment to education, and the accomplished character of affective life consists in the capacity for this kind of attunement. Hence, a meaningful project is possible in the determinate circumstances only when we have successfully attuned ourselves to a specific context. Through such attunement, our open-ended capacity for attunement is itself rendered determinate. The circumstances to which we find ourselves attuned, circumstances as various as small social circles, the fate of a favoured sport team, or issues of educational policy, determine the sense in which we experience our freedom, as well as the extent to which concrete engagement in the world can be a meaningful realization of it. Accordingly, our concrete involvement in the world is a site of real vulnerability - we may or may not find ourselves engaged in projects to which we are genuinely attached or charged with tasks that express and realize a basic commitment. Our affective bonds, in other words, may not be rendered specific and significant in powerful and relevant ways, and our experience of our own freedom depends on this

The projects to which we may become attached are chosen on the basis of significances that are socially constituted. ${ }^{19}$ Examples of these are that in which the good consists, the expectations that attend the lives of individuals, or the various terms by which things are evaluated. ${ }^{20}$ Only because such interpretations are always shared can we be attuned individually to a common world. ${ }^{21}$ Heidegger expresses this idea by stating

\footnotetext{
${ }^{18}$ Consider that, in Being and Time, the disclosedness of equipment refers precisely to the particularity of the context in which it is employed. As Haugeland writes, "The way of equipmental being, its 'actuality' lies in the actual playing of an equipmental role, something actually having that role" (31, emphasis in original).

19 The social constitution of basic significances could be referred to as the "sub-personal" dimension of mood, as does Lauren Freeman in a forthcoming article, "Toward a Phenomenology of Mood." Noting the importance of this dimension for the individual's experience of mood, Freeman writes, "Moods attune us to the public background of being situated in a world" (5). See also Guignon, "Moods in Heidegger's Being and Time."

${ }^{20}$ While I emphasize the role of originary interpretations of significance more than he does, Guignon helpfully describes the social and public character of Dasein's moods ("Moods in Heidegger's Being and Time" 187-188). See also Heidegger, The Essence of Reason.

21 While critical of the indifference characteristic of the "they" [das Man], Heidegger maintains its irreducibility to Dasein: "This undifferentiated character of Dasein's being is
} 
that our state-of-mind is a co-state-of-mind [Mitbefindlichkeit] (BT 205/162). Our possible ways of Being-with-one-another draw on commonalities of affective life that are actively manifest in our interactions with one another. Meanwhile, the constant expression of a basic sense of shared significance mediates our engagements with one another and is substantially relevant to our ability to communicate well with one another. As such, our co-state-of-mind is communicated by discourse: "The intelligibility of Being-in-the-world - an intelligibility that goes with a state-of-mind-expresses itself as discourse" (BT 204/161, emphasis in original). ${ }^{22}$ The shared significance expressed in discourse orients us to a world in a way that is compatible with the orientation of others. As a result, this shared significance is integral to our freedom, both because we assess and choose our projects out of it and because the availability of specific projects, which require social cooperation, depends on it. At the same time, our mutual dependence on shared significance marks this significance as a site of vulnerability. Just as the shared, public character of significance can meaningfully contextualize our involvement with one another, when it is lacking the activities and commitments we take to be worthwhile are themselves limited and changed. ${ }^{23}$

Finally, our responsibility for the basic significance out of which we live, and for the particular projects through which we interpret and realize this significance, is inescapable. ${ }^{24}$ We adopt shared terms and possibilities for the sake of our own existence and, hence, reiterate them in our selfenactment. ${ }^{25}$ As Heidegger explains, to be concerned with our own

not nothing, but a positive phenomenal characteristic of Dasein. Out of this kind of beingand back into it again - is all existing, such as it is" (BT 69/43).

${ }^{22}$ In several ways Heidegger points out that mood is better understood as intrinsic to the phenomenon of communication than as the content of an individual's experience. For example, he reminds us that even though accounts of affect have historically fallen mainly within the rubric of a "psychology," Aristotle's account of the phenomenon, in the second book of Rhetoric, functions as a proto-hermeneutics of public life. To speak well, an orator must discern, "hearken," the mood of a crowd, an ability possible only on the basis of the expressive power of mood (BT 178/138-139).

23 Although it falls outside the scope of this paper, the account of Grundstimmung or fundamental attunement that Heidegger offers in The Fundamental Concepts of Metaphysics would complement my emphasis on the originarilly interpretive character of affective life. For a summary of Heidegger's account of Grundstimmung, see de Beistegui 66-68).

${ }^{24}$ Arguably, a rehearsal of Dasein's mode of authentic individuation would be required for a thorough account of responsibility. I have not offered this here in order to focus more directly on concrete affective life. Crowell explains how the second division of Being and Time describes the background phenomenological condition of autonomy and responsibility.

25 Thus, I hold that we are responsible for even the "disclosive submission" to the world by which Heidegger partially defines Befindlichkeit (BT 177/137). Crowell seems to 
existence is to be concerned with specific possibilities and socially constituted significance: "To say that the 'for-the-sake-of-which' and significance are both disclosed in Dasein, means that Dasein is that which, as Being-in-the-world, is at issue for itself' (182/143, emphasis in original). It is because we matter to ourselves that we are able to choose worldly projects as the expressive media of our existence. To recognize ourselves as choosers, in this respect, is to recognize a responsibility for how and why we choose and for the affective investments that inspire us to make our freedom determinate. Despite this, our responsibility for our own affective lives is not something we necessarily notice, and our failure to notice it is largely conditioned by the world in which we ought to be able to find resources for the kind of critical self-reflection and self-critique that holds us accountable to the freedom inherent in our existence. As a result, our responsibility for our own affective life is another site in which we are fundamentally vulnerable to a world that may prevent us from recognizing meaningfully our freedom. ${ }^{26}$

The three risks we have identified-(a) the possibility that the particular worldly projects we undertake will not reflect meaningful possibilities, (b) the possibility that the basic measures of significance by which we choose our projects will not orient us well, and (c) our vulnerability to a world that may not encourage us to reflect on our own responsibility for the latter two aspects of our free, meaningful existencethreaten to inhibit the basic existential freedom realized through affective life. Having considered how the three risks attending our affective involvement are related, respectively, to the accomplished character of affective life, its public constitution, and our responsibility for it, as well as how these three features of affective life derive from our existential makeup, we are now prepared to turn to Hochschild's sociological analysis of affective labour and to consider how developments in economic life can undermine considerably our capacity to live freely and meaningfully.

\section{Hochschild on Emotion and Affective Labour}

In her 1983 The Managed Heart: The Commercialization of Human Feeling, Hochschild argues that our post-industrial economy fails to

suggest that this is not the case: "Existential feelings cannot be mastered; I cannot make the world as a whole matter to me otherwise than it does. But affective intentional states can be mastered because they are reason-responsive" (Crowell 14); however, the account of autonomy offered further on suggests that each individual is responsible for the meaning in terms of which she experiences herself (Crowell 17, 30-31). My account of our communicative involvement in the realization of what is disclosed existentially should explain my claim that we are responsible for the social constitution of significance.

26 The idea that we are responsible for our own feelings, especially for our collective feelings, is gaining traction in moral philosophy (see Harbin). 
recognize adequately affective labour-emotional work done in a commercial setting. ${ }^{27}$ Her work begins with a robust account of affective life in terms of which she analyses the repercussion, for both individuals and society, of the intrusion of company motives in the affective lives of employees. Our aim, in turning to Hochschild's work, is to relate factors contributing to our contemporary, Western experience of affective life to our analysis of Heidegger's work, and to demonstrate that the demand for affective labour adversely affects our ability to realize meaningfully our freedom. We begin by turning to Hochschild's account of affective life, highlighting especially the role of interpersonal communication in maintaining basic affective experiences associated with shared forms of life. Next, building on the idea that our interactions with one another are sites in which affective life is rendered vulnerable to economic life, we turn to Hochschild's account of affective labour to see how affective labour can inhibit our free, meaningful self-realization. In the subsequent section, we will consider Hochschild's work in relation to Heidegger's.

\section{(a) Hochschild, Emotions, and the Social World}

Hochschild frames her analysis of post-industrial labour relations with a theory of emotions that emphasises the socially constituted and interactive character of affective life. Emotional life, according to Hochschild, involves an immediate and socially constituted reaction, an assessment of this reaction, and an affective response to this assessment. Let us consider each of these. $^{28}$

The first moment, involving an immediate and socially constituted reaction to a situation, plays what Hochschild calls, borrowing from Freud, a "signal function": 29 it renders explicit our investment in the specific contexts, and our ways of being affected by changes in these contexts, by

27 To develop her concept of "pink-collar" labour, Hochschild builds on C. Wright Mills' work in White Collar, from 1956, on the "selling of personality" which results in the selfalienation prevalent in advanced capitalist systems.

${ }^{28}$ By establishing this connection, it should cease to be problematic that Heidegger speaks of "mood" while Hochschild speaks of "emotion." In general, while not clearly delimited in scientific research, moods are considered to be longer lasting than emotions which can arise and fade quickly (see Freeman, ftn xxvii). Guignon's choice of the term "feeling" for mood, and affective life generally, also supports my connection between Heidegger's account of mood and Hochschild's account of emotion (see Guignon, "The Body, Bodily Feelings, and Existential Feelings"). Elpidorou argues extensively that Heidegger's account of mood is compatible with contemporary research in emotions.

${ }^{29}$ Hochschild explains that this first moment corresponds to the "organismic" theory of emotions as it appears in Darwin, Freud, and James. According to the organismic theory, emotions immediately accompany our physiological involvement, and are, therefore, universal and action-oriented. While disavowing the universality and biological rootedness of this theory, Hochschild's retains in her account the immediacy of affective life (230). 
disclosing our attachment to specific circumstances and possibilities. ${ }^{30}$ Hochschild highlights the disclosive character of affective life: "Emotion is a sense that tells us about the self-relevance of reality. We infer from it what we must have wanted or expected or how we must have perceived the world. Emotion is one way to discover a buried perspective on matters" (Managed Heart 85). Our affective reactions are specific to environments and projects, and they reflect a connection between individual projects and the basic possibilities - such as family, education, or artistic expression-that we take our projects to be realizing.

The second moment of Hochschild's account involves an active assessment of our immediate affective reactions. ${ }^{31}$ These assessments are mediated by what Hochschild calls "feeling rules," social norms prescribing how, and to what degree, we ought to feel about a situation. Hochschild writes: "feeling rules set out what is owed in gestures of exchange between people. They enable us to assess the worth of an outward tear or an inward attempt to feel sad" (Managed Heart 76) ${ }^{32}$ For example, an insufficiently enthusiastic response to the good news of a friend could be measured against an appropriate reaction to determine the affective effort an individual owes. Individual affective life could thereby be made to conform to shared interpretations, social roles, and modes of expression. Furthermore, feeling rules capture basic, shared interpretations of significance because the sense that one ought to feel one way or another presupposes basic standards that determine the appropriateness of particular feelings.

The third moment of Hochschild's account consists in what she identifies as "emotional work." Perceiving that we ought to feel a certain way is associated with wanting to be perceived as feeling a certain way and, thereby, communicating what we perceive to be the correct emotional message to those with whom we are involved. To accomplish such communication, we engage in emotional work. This work corresponds not only to superficial shows of feeling; what we take ourselves to owe to others

\footnotetext{
${ }^{30}$ Unlike Freud, however, according to whom the signal function remained tied to anxiety (see Ego and the Id), Hochschild associates the signal function of emotions with the host of diverse and subtle ways that we find ourselves invested in the world and affected by it. For an article that endorses Hochschild's approach while outlining the (mainly epistemological) tensions that surround the use of psychoanalysis for sociology, see Clarke.

${ }^{31}$ This aspect of Hochschild's account draws on the interactionist work of Dewey, Girth, Mead, and Mills.

${ }^{32}$ Elpidorou also argues that "appraisals constitute an essential feature of emotions" (575). Further, he argues that what Heidegger calls "Befindlichkeit" is the condition of possibility of such appraisals (582), a position that is compatible with my account of the social constitution of basic significance.
} 
is actually to feel one way or another about a situation. ${ }^{33}$ Superficially, then, we are responsible for how we feel insofar as we constantly engage in efforts to feel one way or another. More fundamentally, however, we are responsible for reproducing the world defined by the basic interpretations feeling rules express because emotional work implicitly endorses and perpetuates the basic measures that constitutes our shared world.

As Hochschild demonstrates, feeling rules not only mediate our interactions; they are also intimately related to basic structures of social life and to individuals' possibilities of self-definition. Hochschild remarks on the social character of affective life as follows, "All of us try to feel, and pretend to feel, but we seldom do so alone. Most often we do it when we exchange gestures or signs of feeling with others" (Managed Heart 76). Affective life, in other words, is enacted with others and through "feeling rules" that function as implicit norms supporting a co-attunement to a common world. Feeling rules capture, therefore, the basic, shared interpretations constitutive of social and cultural commonalities. Meanwhile, communicative interactions express these and thereby give rise to a specific affective atmosphere. Thus, by mediating our interactions, feeling rules establish and maintain shared standards and interpretations. This function of feeling rules depends upon social rules being embodied and realized within the affective lives of individuals such that the constitutive phenomena of social life - traditions, cultures, and institutions-can be realized through individuals. ${ }^{34}$ Inasmuch as the process of self-shaping depends on feeling rules, we realize ourselves in our interactions with one another and the affective atmospheres characteristic of our shared world are realized in these same interactions. Moreover, inasmuch as feeling rules are maintained in communication, the analysis of feeling rules marks communication as determinative of the specificity of our shared world and our individuality.

Having come to see that the possibilities of affective life are maintained in our interactions with one another, let us now turn to Hochschild's account of affective labour to consider how changes in the economic conditions of our shared world affect precisely such interactions, and, thereby, the character of the world we enact collectively, as well as the affective experiences afforded therein.

\footnotetext{
${ }^{33}$ Hochschild refers here "deep acting” techniques (33).

34 There are significant similarities between Hochschild's account of feeling rules and Bourdieu's account of the habitus. Bourdieu, however, focusses more on the individual's attunement to her potential social advantage (see Logic of Practice 55; "What Makes a Social Class?").
} 


\section{(b) Hochschild on Affective Labour}

Hochschild's analysis of affective labour shows that engineering our communicative interactions in commercial environments deeply impacts the character of the world we share. Tracing the connection between the affective lives of those engaged in affective labour, on the one hand, and the basic accounts of significance particular to companies, on the other hand, will allow us to see how the free self-realization affective life enables is threatened by affective labour. ${ }^{35}$ First, Hochschild's analysis of the experience of airline stewardesses, particularly during the period she identifies as an "industry speed-up," will allow us to consider the relationship between feeling rules and an increasingly unsatisfying social reality. Farther on, we shall aim to understand how changes in our shared environment are the result of changes in communication, and how these are tied to the risks and vulnerabilities of affective life that we associated with Heidegger's work. Let us turn to Hochschild's account of affective labour.

According to Hochschild, emotional labour is emotional work that takes its guidance from feeling rules set by a company and motivated by that company's interest in profit. ${ }^{36}$ She remarks that "roughly one-third of American workers today have jobs that subject them to substantial demands for emotional labour" (Managed Heart 11). She clarifies further that, "Emotional labour occurs only in jobs that require personal contact with the public, the production of a state of mind in others, and (except in true professions) the monitoring of emotional labour by supervisors" (Managed Heart 156, 186). By monitoring strictly the way employees interact with clients, a company can ensure that an atmosphere accomplished by a disavowal of the feelings of employees is maintained (Managed Heart 173). ${ }^{37}$ Specifically, companies deny workers proper access to their own feelings to ensure that interpersonal exchanges in the context of service-

\footnotetext{
${ }^{35}$ Hochschild describes of the impact of institutions on emotional management (49-55).

${ }^{36}$ Hochschild identifies different kinds of jobs involving emotional labour- "professional and technical workers, managers and administrators, sales workers, clerical workers, and service workers of two types, those who work inside and those who work outside of private households" (244). Hochschild's analysis draws on data from the 1970 US census (244251).

${ }^{37}$ Hochschild argues that this situation is considerably worse for women, largely because women are generally expected to be nicer and because their feelings tend not to be recognized as rational (173). For this reason, as well as because most airline service workers were women, I shall refer to "stewardesses" rather than to "stewardesses and stewards." The sexism characteristic of this stage is evident not only in the gendered division of social roles but also in the image of the glamorous stewardess and the airline's interest in the physical appearance, morality, and marital status of employees (see Hochschild 101-102). Hochschild reports that the sexist tendencies embedded in the "overall condition of work [...] were treated as unalterable facts of life. The only question to be seriously discussed was, "How to rid yourself of anger?" (113).
} 
oriented commercial settings create an atmosphere that can be sold by the company. ${ }^{38}$ In general, the (mostly male) clientele should be deferred to and made to feel uniquely important by the (mostly female) airline staff. ${ }^{39}$ In this way, passengers' positive experiences can be reasonably ensured by the stewardesses' emotional labour. More specifically, the airplane should feel like a living room for passengers, a place where they can comfortably relax in the company of individuals who take delight in helping them do so. It was the job of the stewardess to produce this effect by shaping their own affective lives in conformity with feeling rules and modes of interaction set by airlines. The stewardess is asked, for example, to imagine that she is serving guests in her living room so that her treatment of passengers will appear natural and effortless and, thereby, allow the passenger to feel cared for and special (Managed Heart 107). This is the atmosphere that can be bought and sold. Delta's passengers, for example, were promised a "smile from within." Thus, affective labour has two basic products: (1) the product realised in the feelings elicited in clients, and (2) an atmosphere of, most often, enthusiastic deference to clients. Hochschild's descriptions of the experiences of stewardesses and of the advertising on the part of airline companies during the 1950s and 60s bears out these claims. While during this time working conditions supported the ability of employees to perform the required labour, this phase set standards for service and atmosphere that could not be sustained in changing economic environments,

The second phase of airline travel emerged in the 1970s, when restrictions on ticket prices were lifted and airlines could compete by offering lower fares rather than by trying to outdo competitors through service and atmosphere (Managed Heart 121). More passengers to serve, less time to prepare, and longer flight times radically changed working conditions without altering the demand for the worker's emotional labour. At this time, the burdens and changes associated with emotional labour were exposed. The changes in working conditions that highlighted the demands on emotional labour also gave rise to new phenomena-disappointment and alienation on the part of employees and the atmosphere to which these changes corresponded. ${ }^{40}$

\footnotetext{
${ }^{38}$ For Hoshchild's remarks on the explicit character of feelings rules, see Managed Heart 119. For her account of the employee's need to control her own feelings, see Managed Heart 95-114.

${ }^{39}$ Hochschild notes that "of all women working, roughly one half have jobs that call for emotional labour" (11). For works that deal substantially with the feminist implications of Hochschild's account, see Pierce; Hall.

${ }^{40}$ With respect to the experience of alienation on the part of employees, Hochschild's account mirrors Marx's analysis of alienated labour; pink-collar workers become alienated from the product of emotional labour just as the proletariat becomes alienated from the product of material labour (see Managed Heart 17).
} 
While during the first phase, employees could allow themselves to forget that their moods and behaviour were regulated by the company, the second phase exposed the degree to which airlines made demands on employees' sense of self. It also exposed the relationship between the employee's experience of self and the atmosphere created for clients. The employee's experience of herself was tied to the way companies shaped the context in which she interacted with others. Within this context no strategies existed that could lead to an acceptable self-experience. To expand, neither a genuine attempt to provide affective labour nor a disavowal of its importance in light of an overtaxing work situation allowed the employee to meaningfully engage in her work. Those who continued to try to create a sense of intimacy and care for the customers were unable to do so and, therefore, experienced the burden of their own "phoniness." 41 The employee was left to wonder whether she really was a phony or to embrace the need for phoniness and wonder "who" did the job at all. Both experiences forced the employee to engage in "illusion making," a necessary but ultimately unimportant effort to create an illusory sense of customer enjoyment, a sense that customers too generally felt to be contrived. Thus, the feeling rules instituted by companies during the $1970 \mathrm{~s}$ overtaxed the emotional resources of employees and changed the shared social atmosphere in which all engaged.

The burden of emotional labour consists both in demeaning treatment of employees by entitled customers and in the effects of coping techniques employed by employees. It is the coping techniques-the various ways of dissociating the job "self" from the real "self" - that played the greatest role in creating an atmosphere which consisted largely in a feeling of distrust between employees and clients. ${ }^{42}$ As Hochschild writes;

Estrangement from display, from feeling, and from what feelings can tell us is not simply the occupational hazard of a few. It has firmly established itself in the culture as permanently imaginable. All of us who know the commercialization of human feeling at one

${ }^{41}$ For an account of why the burden of phoniness tends to be worse for women, see Simpson and Stroh. According to Hochschild, there are also workers who do not consider affective labour to involve acting. These workers tend to burn out quickly because they experience both positive and negative reactions to their service as a reflection of themselves (Managed Heart 187). I do not focus on such individuals, largely because this way of coping seems to be unsustainable. For essays by Hochschild and others that address emotional exploitation in other jobs, and of women from Third World countries working in the United States, see Ehrenreich and Hochschild.

${ }^{42}$ It may be argued that this kind of distrust is built into the very institutional character of modernity and its orientation towards the individual. Nevertheless, I take myself to be justified in attributing it to the changes in social atmosphere associated with emotional labour insofar as it is a distrust of authenticity of feeling that is at stake. 
remove - as witness, consumer, or critic - have become adept at recognizing and discounting commercialized feeling: 'Oh, they have to be friendly, that's their job.' (Managed Heart 190-191)

It is in this fundamentally false shared reality that a change in atmosphere consists. Affective labor does not just undermine the self-experience of employees, and does not just lead to dull or unsatisfying experiences on the part of clients; it creates a shared reality in which neither meaningfully partake. When our interactions are mediated by affective labour, our very efforts to communicate contribute to the loss of a shared world; we lose the sense that the world is compelling and that the projects we undertake within it are meaningful.

We recognize implicitly the pervasiveness of affective labour in our daily impersonal exchanges. We may fail to notice this, however, but that, "The occasional lapses from the standard of civility that we take for granted remind us of the crucial steadying effect of emotional labor" (Managed Heart 187). By setting the feeling rules that dictate the nature and style of our interactions, companies changed our sense of shared reality-we now expect that people will behave in ways that conceal their real "self." Thus, according to Hochschild, this new shared social atmosphere is characterised by the commodification of affective life, and, therefore, a specific function of communication-one that is geared towards the instrumental maintenance of a civil social world. Hochschild explains that this new reality coincides with the increased prising of spontaneity and authenticity. These values, she notes, are distinctly modern - they arose only when superficiality and insincerity in relation to others, and to one's self, became the norm. Put otherwise, the premium we put on what we perceive as "natural feeling" is a reaction to the commercialization of feeling, what Hochschild calls the "managed heart." She describes the "managed heart" as "the rise of the corporate use of guile and the organized training of feeling to sustain it" (Managed Heart 192). Organizations have subordinated private emotional systems - those that open us to a world, to one another, and to what we have in common - to a commercial logic (Managed Heart 185-186). In this we must recognize that our shared institutions are both changed and changing us.

Hochschild expresses a real cost of the commercialization of feeling in language reminiscent of our analysis of Heidegger's work: "And when we lose access to feeling, we lose a central means of interpreting the world around us" (Managed Heart 188). ${ }^{43}$ Affective life opens the world for us by

${ }^{43}$ Compare de Beistegui's description of a contemporary humanity characterised by profound boredom: "This means that the contemporary Dasein is cut off from himself as Dasein (as the ek-sistent being, or as the being who is being, who is the 'there' or the clearing of being), oblivious to the Dasein in him, and this means to his essence, to the 
disclosing it in terms of what matters to us, and it is precisely this experience of meaningful disclosure that is threatened by the "managed heart." As Hochschild explains, "It is from feeling that we learn the self-relevance of what we see, remember, or imagine. Yet it is precisely this precious resource that is put in jeopardy when a company inserts a commercial purpose between a feeling and its interpretation" (Managed Heart 196). The manipulation of feeling by companies is, as Hochschild notes, a very real threat to our ability to live in a world that matters to us because the commercialization of feeling acts on that mechanism, that existential structure, by which the world is rendered meaningful.

\section{(c) Heidegger and Hochschild}

Embedded in her robust account of affective life, Hochschild's concrete analysis of affective labour affords an example of both the nature and vulnerability of affective life. Before elaborating on the vulnerabilities of affective life and their relationship to our potential for meaningful experiences of freedom, let us clarify how Hochschild's account is related to Heidegger's and consider Heidegger's own way of explaining the centrality of communication for our experience of ourselves as free.

First, just as Heidegger's work encouraged us to understand the accomplished character of affective life as a concrete attunement to a specific situation, we saw, in the context of Hochschild's work, the role played by the signal function of emotion: it discloses our embeddedness in a particular situation that affects us one way or another. Next, the socially constituted character of affective life, as we came to understand it in the context of Heidegger's work, referred to a shared orientation to a world that matters, especially as this orientation involves submission to culturally and historically specific standards. Relatedly, Hochschild's emphasis on feeling rules recalls the socially constituted character of affective life we identified in Heidegger's work; only as shared and expressive of communally held standards do feeling rules regulate the affective lives of individuals in ways compatible with a diverse social reality. ${ }^{44}$ Finally, the responsibility for our own affective life associated with Heidegger's work relates both relatively superficially and more substantially to what Hochschild identifies as emotional work: by making an effort to feel a certain way in response to feeling rules, we find ourselves responsible for both the particularities of

point of no longer being able to act on his essence or his freedom" (75-76, emphasis in original).

${ }^{44}$ Hochschild is criticised for failing to distinguish clearly between "private" emotional life, and emotional life as it has been rendered instrumental by post-Fordist capitalism. This is largely because she both acknowledges that our private emotional experience is always influenced and mediated by a variety of roles and institutions, and opposes private emotional experience to emotional life in the service of capitalist interest (see Weeks; Wouters). 
our feelings and the projects to which they correspond and, more fundamentally, for the shared standards that we enact and perpetuate in our efforts to conform. The two views converge, then, in the three aspects of affective life we found to be implicit in Heidegger's account of affective life.

Thus far, Hochschild's analysis of the experience of stewardesses has demonstrated that it was by manipulating our modes of communication that airlines acquired a product to sell. Let us now turn to an Heideggerian understanding of communication to clarify the existential dimensions of the relationship between communication and affective life. More specifically, Heidegger's work will enable us to see that the dimensions of affective life that embed us in situations through a submission to shared experiences of meaning are themselves dependent upon our ways of seeing the world together, upon communication.

Heidegger's account of communication is related to the social and public character of affective life analysed above and focusses on the essentiality of shared perspectives in the constitution of social reality and on the role of communication in the development of shared perspectives. ${ }^{45}$ Through our co-state-of-mind - our submission to shared standards and coattunement to the significance of things-we realize cooperatively the intelligibility of the world. Heidegger characterises communication, meanwhile, as the enactment of such co-attunement, as "(1)letting someone see with us what we have pointed out" (BT 197/155). To communicate is to develop or perpetuate a shared perspective on things, a perspective that both constitutes our sense of ourselves and discloses to us our world:

That which is 'shared' is our Being-towards what has been pointed out - a Being in which we see in common. One must keep in mind that this Being-towards is Being-in-the-world, and that from out of this very world what been pointed out gets encountered. (BT 197/155)

Communication enables the world into which each of us projects ourselves individually to be a shared world. The character of this sharing consists in a "seeing in common" that is equally an inclination towards that which we recognize collectively. A world is thus realized in shared perspectives and in compatible and cooperative inclinations, themselves enabled as and through communication. Communication enables us to take seriously and remain attached to shared but contingent terms - it inclines us to the world we build together, allowing us to experience a co-attunement as a shared

45 Nevertheless, describing that which is interpreted by Dasein, Haugeland notes, "whatever is to be interpreted must always already belong to and be construed in terms of a common institutional framework" (33, emphasis in original). 
affective atmosphere. Thus, basic states-of-mind are inseparable from the determinate ways we share a world, especially from the social, political, and economic norms that mediate our interactions.

Both Hochschild and Heidegger demonstrate, then, that communication is central to the experience of the world to which we are attuned. Hochschild's analysis highlights the concrete repercussions for the self-experience of employees expected to perform emotional labour and for a shared sense of a meaningful reality in which to participate. Heidegger's account of communication, meanwhile, clarifies the existential aspects of our shared experience of significance, and of the irreducibly social character of the bonds through which we realize ourselves as free. In both cases, the centrality of communication to affective life highlights the vulnerability of that life: affective life is the medium of our relatedness to others and the foundation of shared ways of experiencing the world - of the institutions, traditions, and customs that form the background of the familiar worlds we recognize as our own. ${ }^{46}$ It is these, as well as our self-experience, that are vulnerable to changes in how we communicate.

\section{(d) Existential Vulnerabilities of Affective Life and the Social Constitution of Freedom}

Returning to the three risks we associated with affective life in our analysis of Heidegger's work will allow us to conclude that the commercialization of feeling poses a very real threat to our capacity to live meaningfully and that it does so not only by undermining the affective lives of individuals, but also by giving rise to a world devoid of shared meaningful interpretations of significance. Attending to the vulnerabilities to which affective life exposes us, as we shall see, also clarifies the social character of our freedom, which itself can be realized only in a world that protects us from the vulnerabilities constitutive of our existence.

As we saw above, the accomplished character of affective life corresponds to the risk that our feelings will not be associated with an actual state of affairs, and, relatedly, to the risk that the specific projects we undertake will fail to realize a meaningful possibility. Existentially speaking, we risk being unable to see ourselves in the possibilities of our world, and therefore, risk being deprived of the experience of self for whom a meaningful realization of freedom is possible. Such a loss of self corresponds to the worker's alienation from the feelings of clients, the product of her labour. To elicit certain feelings in clients, or to endure their demands and disappointments, the employee must abstract constantly a dimension of affective life from her capacity for meaningful involvement.

\footnotetext{
${ }^{46}$ Hochschild's analysis of affective life touches on an issue that arises prominently in Emile Durkheim's work, specifically, the social constitution of the individual and the effect of different modes of social association on the individual, (see Division of Labour 288).
} 
Thereby, the employee alienates herself from that part of herself that is actively engaged in managing her feelings, an alienation that amounts to a renunciation of that aspect of affective life that ties her to a meaningful state of affairs. Without such a meaningful possibility she cannot make productive and significant her affective bonds with the world by associating them with a domain in which her actions have substantial purchase. Thus, artificial affective attachments prey upon the first vulnerability of affective life by preventing a genuine convergence of our affective attachment and our circumspective involvement. In so doing, they undermine considerably the meaningful realization of freedom, specifically, by depriving us of the experience of the disclosure of freedom as the capacity to act in a context that matters to us

The second vulnerability associated with affective life - that we are dependent on the world for the basic terms with which to measure and assess the significance of our projects - is also exacerbated by the demand for affective labour. When feeling rules are instituted by companies, our interpersonal exchanges have an increasingly tenuous link to basic shared terms of significance. Indeed, the establishment of feeling rules by companies means that the shared social reality in which we engage simply does not realize shared significance. Instead, the basic significance on which we all come to rely is the company's orientation towards profit. ${ }^{47}$ Furthermore, when the feeling rules that mediate our relations are emptied of content, we find ourselves deprived of our capacity to relate to others as co-participants in our shared world. Hence, the second vulnerability associated with affective life is exacerbated in two ways-one in that we are alienated from pre-established significance and two in that our modes of interaction realize neither old nor new significance. As a result, we find ourselves deprived of meaningful measures in terms of which to choose our projects and to share our world with others. Our freedom is thereby threatened inasmuch as we find ourselves without the basic interpretations on which we depend in order to be able to recognize independently the value and significance of actual or potential projects.

Lastly, the rise of affective labour undermines our capacity to recognize our responsibility for our affective life, thereby limiting our capacity to recognize the freedom inherent therein. This third vulnerability follows from the two previous ones: without a proper connection between our affective lives and our concrete projects, and without basic assessments of significance by which to choose and assess our projects, we find ourselves deprived of the two important aspects of self-experience in which our responsibility lies. As we may recall, the experience of attachment to

47 In his essay, "The Question Concerning Technology," Heidegger denounces an orientation towards profit that he sees as essential to modern technology and, by extension, capitalism. 
the world that is realized as affective life is also always an experience of the way of being that constitutes our existence. We are not discrete selves; we are instead beings whose "selves" are manifest in a meaningful projection of world as affective bonds with that world. We must recognize our responsibility to recognize the nature of our freedom, which consists in its dependence on the world in which we find ourselves: to recognize our freedom, we need projects that enable us to recognize our freedom as the capacity to act in contexts in which meaningful possibilities are realized, and we need basic accounts of significance in order to choose such projects. ${ }^{48}$ Both substantial projects and the measures by which they are assessed disclose our freedom in a meaningful way only to the degree that they enable us to recognize the responsibility inherent in both adopting and interpreting a meaningful world. The increase in affective labour realizes the risk that we will fail to recognize our responsibility for affective life because this increase gives rise to a world more and more devoid of meaningful projects and measures by which to choose or invent projects.

\section{Conclusion}

By revealing the impact of affective labour on the vulnerabilities of affective life, and by understanding these vulnerabilities to be associated with the role of affective life in the meaningful realization of our freedom, we have come to see that affective labour can substantially undermine human freedom. We have also found that the relationship between human freedom and affective life is mediated by shared interpretations of significance and the communicative interactions by which these are adopted, realized, and maintained. We have seen, in other words, the inherently social character of freedom as it is articulated in our shared interpretations and the various formal and informal institutions to which they correspond. Our responsibility for our own affective life, therefore, has been shown to be a responsibility to choose projects through which a freedom that is shared can be realized, and to recognize the worldly significance, or lack thereof, that informs our choices.

If Hochschild's analysis has convinced us of the dangers of affective labour, and the analysis of Heidegger's account of state-of-mind has convinced us of its relationship to responsibility and freedom, then we must also recognize that we continue to live in a world in which the meaningful realization of freedom and the individual sense of responsibility for this situation remain underdeveloped. The 2012 Community Survey of the

${ }^{48}$ Heidegger considers and expands on the human capacity to live meaningfully in Contributions. For an account of Heidegger's position, see Held. It is noteworthy, however, that Held disagrees with Heidegger's pessimistic dismissal of the modern, liberal institutions that shape our world ("Fundamental Moods" 299-300). 
American census indicates that jobs in the service industry make up $18.3 \%$ of civilian employees 16 years or over. Sales and office occupations account for another $24.5 \%$ (Census Bureau 2012). Hence, in the roughly thirty years since Hochschild's analysis, affective labour remains prominent. Its prominence, however, in no way reduces our responsibility to recognize the character of our freedom and its location in the bonds to the world through which we experience ourselves, each other, and what we have in common. Without these, we are unable to live in the world in a way that matters to us. Moreover, if Hochschild has attuned us to concrete instances of such problems, Heidegger's work remain essential to understanding the affective dimensions of our existential freedom, and is, I contend, an important supplement to analyses of concrete dimensions of human life, as well as a ground-breaking ontological analysis.

\section{Works Cited}

BOURDIEU, P. The Logic of Practice. Trans. Richard Nice. Stanford: Stanford University Press, 1990.

-. "What Makes a Social Class? On the Theoretical and Practical Existence of Groups." Trans. L. J. D. Wacquant and D. Young. Berkeley Journal of Sociology 32, 1987, 1-17.

CLARKE, S. "Theory and Practice: Psychoanalytic Sociology." Sociology 40.6, 2006, 1153-1169.

COLETTI, Lucio. Marxism and Hegel. Trans. L. Garner. London: Verso, 1979.

CROWELL, Steven. "Responsbility, Autonomy, Affectivity." Presented at The German Philosophy Workshop, University of Chicago (201304-19).

Web.http://cas.uchicago.edu/workshops/germanphilosophy/files/20 13/04/Responsibility-Autonomy-Affectivity-final-1.pdf. Accessed July 31, 2014.

—. "Conscience and Reason: Heidegger and the Grounds of Intentionality." Transcendental Heidegger. Ed. S. Crowell and J. Malpas. Stanford: Stanford University Press, 2007, 43-62.

De BEISTEGUI, M. Thinking with Heidegger: Displacements. Bloomington: Indiana University Press, 2003. 
DREYFUS, H. "Heidegger's Ontology of Art." A Companion to Heidegger. Ed. H. Dreyfus and M. A. Wrathall. Cambridge: Blackwell Publishing Ltd. 2005, 407-419.

DURKHEIM, E. The Division of Labour in Society. Trans. W.D. Walls. New York: The Free Press, 1984.

EHRENREICH, B. and Hochschild R.A., Eds. Global Woman: Nannies, Maids and Sex Workers in the New Economy. New York: Henry Holt and Company, 2002.

FLATLEY, J. Affective Mapping: Melancholia and the Politics of Modernism. Cambridge: Harvard University Press, 2008.

FEEMAN, L. "Toward a Phenomenology of Mood.” The Southern Journal of Philosophy. Forthcoming, 2014.

FREUD, S. The Ego and the Id: The Standard Edition. Ed. J. Strachey. New York: W.W. Norton and Company Inc. 1960

GUIGNON, C. "The Body, Bodily Feelings, and Existential Feelings: A Heideggerian Perspective." Philosophy, Psychiatry, and Psychology 16.2, 2009, 195-199.

—. "Moods in Heidegger's Being and Time." What is an Emotion? Classic and Contemporary Readings. Second Edition. Ed. R. Solomon and C. Calhoun. Oxford: Oxford University Press, 2003.

HALL, E. "Smiling, Deferring, and Flirting: Doing Gender by Giving Good Service." Work and Occupations 20.4, 1993, 452-471.

HARBIN, A. "Collective Responsibility and Collective Feeling." Dialogue: Canadian Philosophical Review 53.1, 2014, 31-42.

HAUGELAND, J. "Dasein's Disclosedness." Heidegger: A Critical Reader. Ed. H. Dreyfus \& H. Hall. Cambridge: Blackwell Publishers, 1992.

HEIDEGGER, M. Being and Time. Trans. J. Macquarrie \& E. Robinson. Oxford: Blackwell, 1962.

-. The Essence of Reason. Trans. T. Mallick. Evanston: Northwestern University Press, 1969. 
-. On the Way to Language. Trans. P. D. Hertz. New York: Harper One, 1971.

-. The Question Concerning Technology and Other Essay. Trans. W. Lovitt. New York: Harper Perennial, 1977.

- The Fundamental Concepts of Metaphysics. Trans. W. McNeil and N. Walker. Bloomington: Indiana University Press, 1995.

—. Pathmarks. Ed. W. McNeill. Cambridge: University of Cambridge Press, 1998.

-. Contributions to Philosophy (From Enowning). Trans. P. Emad and K. Maly. Bloomington: Indiana University Press, 1999.

—. Zollikon Seminars: Protocols-Conversations-Letters. Trans. F. Meyer. Ed. M. Boss. Evanston: Northwestern University Press, 2001.

-. Off the Beaten Track. Ed. J. Young and K. Haynes. Cambridge: Cambridge University Press, 2002.

HELD, K. "Fundamental Moods and Heidegger's Critique of Contemporary Culture." Reading Heidegger: Commemorations. Ed. J. Sallis. Bloomington: Indiana University Press. 1993, 286-303.

HOCHSCHILD, A. The Managed Heart: The Commercialization of Human Feeling. London: University of California Press, 1983.

KISIEL, T. The Genesis of Heidegger's Being and Time. Los Angeles: University of California Press, 1993.

MALABOU, C. The Heidegger Change: On the Fantastic in Philosophy. Trans. P. Skafish. New York: State University Press, 2001.

MILLS, C.W. White Collar: The American Middle Classes. New York: Oxford University Press, 1956.

PIERCE, J. Gender Trials: Emotional Lives in Contemporary Law Firms. Oakland: University of California Press, 1995.

RATCLIFFE, M. "Heidegger's Attunement and the Neuropsychology of Emotion." Phenomenology and the Cognitive Sciences 1, 2002, 287312. 
RAWLS, J. A Theory of Justice. Cambridge, Massachusetts: The Belknap Press of Harvard University Press, 1971.

RICHARDSON, Richardson, William J. Heidegger: Through Phenomenology to Thought. The Hague: Martinus Nijhoff, 1963.

SCOTT, Charles E. The Question of Ethics: Nietzsche, Foucault, Heidegger. Bloomington: Indiana University Press. 1990.

SIMPSON, P. A. and Stroh, L. K. "Gender Differences: Emotional Expression and Feelings of Personal Inauthenticity." Journal of Applied Psychology 89.4, 2004, 715-721.

STEINBERG, R. and Figart, D. "Emotional Labour Since: The Managed Heart." The Annals of the American Academy of Political and Social Science 561.1, 1999, 8-26.

United States. American Community Survey. Table S2406: Population Division. Occupation by Class of Worker for the Civilian Population 16 Years and Over. 2011. Washington: US Census Bureau. http://factfinder2.census.gov/faces/tableservices/jsf/pages/productv iew.xhtml?pid=ACS_12_1YR_S2406\&prodType=table. Accessed July 23, 2014.

WEEKS, K. "Life Within and Against Work: Affective Labor, Feminist Critique, and Post-Fordist Politics." Theory and Politics in Organization 7.1, 2007, 233-249.

WOUTERS, C. "The Sociology of Emotions and Flight Attendants: Hochschild's Managed Heart." Theory, Culture \& Society 6.1, 1989, 95-123.

ZIAREK, Krzysztof. “Trading in Being: Event, Capital, Art.” Gatherings: The Heidegger Circle Annual 2, 2002,1-23.

ZIMMERMAN, M. E., Heidegger's Confrontation with Modernity: Technology, Politics, Art. Bloomington: Indiana University Press, 1990. 